\title{
Change of Taste Sensitivity of Clove Cigarette Smokers in Medan
}

\author{
Marlina Simamora ${ }^{1}$, Ameta Primasari ${ }^{2}$ \\ ${ }^{1}$ Undergraduate Program, Faculty of Dentistry, University of Sumatera Utara, Medan 20155, Indonesia \\ ${ }^{2}$ Department of Oral Biology, Faculty of Dentistry, University of Sumatera Utara, Medan 20155, Indonesia \\ Corresponding e-mail to: marlina.oktafia@gmail.com
}

\begin{abstract}
Tongue has taste buds that contain taste receptor which affected by many factors, including smoking habit. Objective: To analyze the differences of sweet and bitter taste sensitivity in the pedicab driver clove cigarette smokers compared to non-smokers in Medan Padang Bulan. Methods: This study was conducted by placing the sweet taste strips and bitter taste strips on four taste receptors of the tongue, with increasing solution concentration in 74 subjects. This was a cross sectional study on pedicab driver population in Medan Padang Bulan. Results: There were differences between clove cigarette smokers and non-smokers on sweet taste examination $(p<0.005)$. There was a difference between clove cigarette smokers and non-smokers on examination bitter taste receptors $(p<0.005)$. On the clove cigarette smokers, there was no significant difference between sweet taste and bitter taste on the receptors itself. Conclusion: Non-smokers are more sensitive to sweet taste than the clove cigarette smokers. Bitter taste sensitivity is greater in cigarettes smokers than in non-smokers. Taste receptors on all location of the tongue could taste sweet and bitter substances, but a certain location of taste receptors were more sensitive compared to others.
\end{abstract}

\begin{abstract}
ABSTRAK
Perubahan sensitifitas rasa pada perokok di Medan. Lidah memiliki taste buds yang mengandung reseptor yang dapat dipengaruhi oleh berbagai macam faktor termasuk kebiasaan merokok. Tujuan: Menganalisis perbedaan sensitifitas rasa manis dan pahit pada supir becak dengan dan tanpa kebiasaan merokok di wilayah Medan Padang Bulan. Metode: Penelitian ini dimulai dengan memberikan kertas rasa manis dan pahit pada seluruh reseptor rasa di lidah dengan konsentrasi yang meningkat pada 74 subjek. Disain penelitian ini adalah lintas potong pada populasi supir becak di wilayah Medan Padang Bulan. Hasil: Terdapat perbedaan bermakna terhadap sensitifitas rasa manis antara perokok dan bukan perokok $(p<0.005)$. Terdapat perbedaan bermakna terhadap sensitifitas rasa pahit antara perokok dan bukan perokok $(p<0.005)$. Tidak terdapat perbedaan yang bermakna antara sensitifitas rasa manis dan pahit pada populasi perokok. Simpulan: Supir becak tanpa kebiasaan merokok memiliki taste buds yang lebih sensitif terhadap rasa manis dibandingkan perokok. Sensitifitas rasa pahit lebih tinggi di kelompok perokok. Reseptor rasa pada seluruh permukaan lidah dapat mengenali rasa manis dan pahit namun reseptor rasa pada lokasi tertentu lebih sensitif dibandingkan yang lain.
\end{abstract}

Key words: sensitivity of taste receptors, smokers, tongue

\section{INTRODUCTION}

Sense of taste consists of taste buds which covering the entire surface of the tongue. Taste buds contain the receptors that sense sour, salty, sweet, bitter and umami. Outer ends of the taste buds arrayed around the taste pore are very small. From the end of each cell, microvilli protrudes out of taste pore and leads to the oral cavity. ${ }^{1}$ Microvilli is considered to provide surface receptors for tasting. Some of the nerve fibers are stimulated by taste receptor cells. The invaginated taste cell membrane folds are also shaped by many vesicles. These vesicles contain neurotransmitter substances that are released through cell membrane to stimulate the ends of the nerve fibers in their res-ponse to the taste. ${ }^{2}$ Sense of taste is influenced by many factors such as age, temperature of food, disease and oral hygiene. Oral hygiene is also associated with smoking. ${ }^{3}$

Smoking habits most potentially cause decreased sense of taste sensitivity. The oral cavity is easily exposed to the harmful effects of smoking since it is the 
beginning of the absorption of the burning cigarette. The negative effects of smoking on dental and oral soft tissues varies, depending on the age, gender, lifestyle, type of cigarettes, duration of smoking and the daily consumption of cigarettes. ${ }^{3}$ In 2008, the World Health Organization (WHO) has set Indonesia as the third-largest country in the world with cigarette users as much as 65 million smokers. In Indonesia, clove cigarettes are the most popular type and the smokers generally in the lower middle social-economic class. ${ }^{4}$

In general, pedicab drivers are in the low-income people category and usually have low educational background. A study in the United States have confirmed the close relationship between smoking and the smoker's educational background. ${ }^{5}$ Pedicab driver had been known to have smoking habit.It is also reported that the prevalence of smoking by $96.1 \%$ on a pedicab driver in Semarang. ${ }^{6}$ The high prevalence of smoking in pedicab driver is caused by several factors, including: lack of knowledge about the dangers of smoking and the difficulties to understand the warning signs on cigarette package. Influence from close acquintances is mostly the reason of all smoking habit and additionally the pleasant perception obtain during smoking.?

Chemicals dissolved in saliva will make contact and stimulate the ends of nerve fibers. It raises impulse that will spread to the facial nerve (nerve VII) and glossopharyngeal nerve (IX). Impulses from an area other than the tongue go through the vagus nerve (X). Those three nerve impulses in the medulla oblongata will unite together into the nucleus tract solitarius. From there, axons carry signals to set off and gather with the medial leminiskus that will be distributed to the insula. The impulses are projected to the cerebral cortex in the postcentral gyrus to the thalamus and as the result; we can taste the food inside our mouth. ${ }^{8}$

This study was supported by the theory that explains when a cigarette is smoked; nicotine in the cigarette is condensed into the oral cavity and may stick to the teeth, tongue and taste buds. Constant irritation from the burning tobacco causes oral mucosal tissue thickening. This leads to easier nicotine deposition that block the taste bud, consequently, interaction of nutrients into the taste receptor will be reduced. ${ }^{3}$ The aim of this study was to provide a better understanding of the differences in the taste buds sensitivity on clove-cigarette smokers with non-smokers. Furthermore, this study was also aimed to determine the most affected taste receptor toward sweet or bitter taste.

\section{METHODS}

The study was an observational analytic study with cross sectional design. This was a non-experimental research to study the correlation between smoking and the effect of risk factors that decrease the sensitivity of taste buds. Materials used in this study were sucrose solution with four different concen-trations $(0.05,0.1$, 0.2 and $0.4 \mathrm{~g} / \mathrm{mL}$ ); quinine hydro-chloride solution with four different concentrations $(0.0004,0.0009,0.0024$ and $0.006 \mathrm{~g} / \mathrm{mL}$ ) and aquadest. ${ }^{9}$ Subjects used in the present study were pedicab drivers in Medan Padang Bulan who were operating in the area around University of Sumatera Utara. The inclusion criterias were as follows: non smoker group (group I): men aged 40-60 years, generally healthy, without smoking history and have no ulceration or abnormality of the tongue. The clove-cigarette smokers group (group II), were men aged 40-60 years who had been smoking at least 5 cigarettes per day during the last 3 years.

Sense of taste sensitivity study was conducted using taste strips paper scoring method. ${ }^{10}$ Taste strips made from filter paper, were the tools used to test the taste buds sensitivity. The paper sized 2 x $8 \mathrm{~cm}$ were drained after it was dipped into sucrose or quinine hydrochloride solution with various concentrations. ${ }^{10}$ Initially, the two subject groups were instructed to rinse their mouth with $60 \mathrm{ml}$ distilled water. Each subject was instructed to pull the tongue out. Saliva presented on the tongue surface was dried using cotton roll to prevent saliva contamination. Taste strips were then placed over the four regions of the tongue, where taste receptors are located. Each area was tested with 4 different solution concentrations, started from the lowest to the highest concentration.

For sweet and bitter taste examination, the taste strips were placed at the tip of the taste receptors (sweet/ salty/ sour/bitter) (Figure 1). The taste receptors were tested and marked positive $(+)$ for a sweet taste and bitter taste that can be interpreted and negative (-) for sweet and bitter taste that can not be interpreted.

Scoring method was standardized. A score of 4 meant the subjects could perceive a sense, starting from the lowest concentration, or all flavor concentrations could be perceived correctly. A score of 3 indicated that the subjects could perceive a sense, starting from the second concentration. A score of 2 indicated that the subjects could perceive a sense starting from the third concentration. A score of 1 indicated that the subject could perceive only the highest concentrations and a score of 0 meant that the overall concentration of flavor could not be perceived correctly by the subject. Processing and data analysis was performed using SPSS computer program with Mann-Whitney Test. The test was chosen due to due to the ordinal measurement scale of the group and the data was not normally distributed.

\section{RESULTS}

The subjects were 37 clove-cigarette smokers and 37 non-smokers . Each subject in both groups was given taste strips of sweet taste and bitter taste on the 
tongue taste receptors with a gradually increasing concentration. Subjects were observed and asked their sensation on sweet or bitter taste.

Table 1 showed that the sweet taste examination on the sweet taste receptor has the highest mean score of 3.13. This indicated that when sweet taste strips placed on where the sweet taste receptor were located, subjects could perceive a sweet taste on the second concentration $(0.1 \mathrm{~g} / \mathrm{mL})$, and could perceived sweet taste of third concentration $(0.2 \mathrm{~g} / \mathrm{mL})$ on salty, sour and bitter receptors. Moreover the bitter taste examination in the bitter taste receptor has the highest mean score 3.32. This indicated that when bitter taste strips placed on the location of bitter taste receptor, subjects could sense it straight away at concentration $(0.0009 \mathrm{~g} / \mathrm{mL})$, while receptors on other location might perceive bitter taste on a slightly higher concentration $(0.0024 \mathrm{~g} / \mathrm{mL})$. Table 2 showed the Mann-Whitney test statistic between the clove cigarette smokers and non-smokers. There was significant difference between smokers and non-smokers in the sweet taste examination for the sweet taste receptor ( $p=0.003)$. Furthermore, there was a difference between smokers and non-smokers in the sweet taste examination for the salty taste receptor ( $p=0.035$ ). This indicated that there were significant differences in the sensitivity of sweet taste buds between clove cigarette smokers and non-smokers. In other words, the nonsmokers were more sensitive to feel the sweet taste on sweet taste receptors than smokers. Besides, there were also significant differences in the sensitivity of salty taste on sweet taste receptors in the clove cigarette smokers and non-smokers. Non-smokers were more sensitive to taste salty and sweet taste on sweet taste receptors than smokers. On the sour and bitter receptors, sensitivity of sweet taste between smokers and non-smokers did not differ significantly.

Mann-Whitney test statistic between the smokers and non-smokers showed that there was difference between smokers and non-smokers in the bitter taste examination for bitter taste receptors $(p=0.001)$ (Table $3)$. This indicated that there were significant differences between clove smokers and non-smokers in the sensitivity of taste buds for bitter taste only on bitter receptors. In other words, the sensitivity of bitter taste was greater in non-smokers than smokers, while no significant difference was found in the sweet, salty and sour taste receptors.

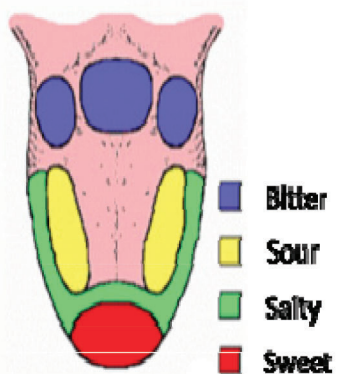

Figure 1. Taste receptors of the tongue
Table 1. The average score of sweet and bitter taste tested on all receptors

\begin{tabular}{cccc}
\hline $\begin{array}{c}\text { Taste } \\
\text { receptors }\end{array}$ & $\begin{array}{c}\text { Taste } \\
\text { examination }\end{array}$ & N & Mean \\
\hline \multirow{2}{*}{ Sweet } & Sweet & 74 & 3.13 \\
& Bitter & 74 & 2.16 \\
Salty & Sweet & 74 & 2.00 \\
& Bitter & 74 & 2.28 \\
Sour & Sweet & 74 & 2.08 \\
& Bitter & 74 & 2.36 \\
Bitter & Sweet & 74 & 2.16 \\
& Bitter & 74 & 3.32 \\
\hline
\end{tabular}

Table 2. Comparative examination of the sweet taste between clove cigarette smokers and non-smokers on sweet, salty, sour, and bitter receptors

\begin{tabular}{ccccc}
\hline $\begin{array}{c}\text { Taste } \\
\text { Receptors }\end{array}$ & Group & $\begin{array}{c}\text { Examination } \\
\text { percent } \\
(\%)\end{array}$ & $\begin{array}{c}\text { Mean } \\
\pm \text { SD }\end{array}$ & $\boldsymbol{p}$ \\
\hline Sweet & S & 30.64 & $2.78 \pm 1.058$ & $0.003^{*}$ \\
& NS & 44.36 & & \\
Salty & S & 32.42 & $1.76 \pm 1.278$ & $0.035^{*}$ \\
& NS & 42.58 & & \\
Sour & S & 32.80 & $1.84 \pm 1.323$ & 0.052 \\
& NS & 42.20 & & \\
Bitter & S & 35.72 & $2.08 \pm 1.233$ & 0.458 \\
\hline
\end{tabular}

$\mathrm{S}=$ smokers, NS=non-smokers, ${ }^{*}$ significant if $p<0.05$

Table 3. Comparative examination of a bitter taste in smokers and non-smokers on sweet, salty, sour and bitter receptors

\begin{tabular}{ccccc}
\hline $\begin{array}{c}\text { Taste } \\
\text { receptors }\end{array}$ & Group & $\begin{array}{c}\text { Mean } \\
\text { Examination } \\
(\%)\end{array}$ & $\begin{array}{c}\text { Mean } \\
\pm \text { SD }\end{array}$ & $\boldsymbol{p}$ \\
\hline Sweet & $\mathrm{S}$ & 35.46 & $2.03 \pm 1.280$ & 0.394 \\
& $\mathrm{NS}$ & 39.54 & & \\
Salty & $\mathrm{S}$ & 33.23 & $2.03 \pm 1.343$ & 0.071 \\
& $\mathrm{NS}$ & 41.77 & & \\
Sour & $\mathrm{S}$ & 35.51 & $2.24 \pm 1.300$ & 0.402 \\
& $\mathrm{NS}$ & 39.49 & & \\
Bitter & $\mathrm{S}$ & 30.04 & $2.97 \pm 1.013$ & $0.001^{*}$ \\
& $\mathrm{NS}$ & 44.96 & & \\
\hline
\end{tabular}

$\mathrm{S}=$ smokers, NS=non-smokers, *significant if $p<0.05$

Table 4. Comparative examination of sweetness and bitter taste receptors sweet, sour, salty and bitter clove smokers with Mann-Whitney Test

\begin{tabular}{ccccc}
\hline $\begin{array}{c}\text { Taste } \\
\text { Receptors }\end{array}$ & $\begin{array}{c}\text { Taste } \\
\text { Examination }\end{array}$ & $\begin{array}{c}\text { Mean } \\
\text { Examination } \\
(\%)\end{array}$ & $\begin{array}{c}\text { Mean } \\
\pm \text { SD }\end{array}$ & $\boldsymbol{p}$ \\
\hline \multirow{2}{*}{ Sweet } & Sweet & 43.45 & $2.41 \pm 1.227$ & $0.014^{*}$ \\
& Bitter & 31.55 & & \\
\multirow{2}{*}{ Salty } & Sweet & 35.15 & $1.89 \pm 1.309$ & 0.336 \\
& Bitter & 39.85 & & \\
Sour & Sweet & 34.18 & $2.04 \pm 1.318$ & 0.173 \\
& Bitter & 40.82 & & \\
\multirow{2}{*}{ Bitter } & Sweet & 29.96 & $2.53 \pm$ & $0.002^{*}$ \\
& Bitter & 45.04 & 1.208 & \\
\hline
\end{tabular}

*Significant if $p<0.05$ 
There was a significant difference between the taste examination of sweet taste and bitter taste $(p=0.014)$. This indicated that the most affected taste sensitivity in smokers were on sweet taste receptors. There was no significant difference between examination of sweet taste and bitter taste, their taste sensitivity to sweet and bitter taste did not differ significantly in smokers. There were significant differences between sweet taste examination with bitter taste $(p=0.002)$, indicated that bitter taste receptor was the most affected taste sensitivity among smokers.

\section{DISCUSSION}

In this study, the subjects were selected by a sampling method which initially performed by conducting the questionnaires to meet the criteria. Subjects with good general health condition, did not consume any kind of cigarettes, without any injuries or abnormalities of the tongue, and did not have the habit of consuming alcohol and betel-chewing. While the smoker group (group II) were smokers who had consumed at least 5 cigarettes per day during the last 3 years until the time of the study taken. ${ }^{10}$

The sweet taste can be felt across the surface of the tongue, but the more dominant taste receptors for sweet taste at the tip of the tongue where there is a proven average score checks sweetness in the sweet taste receptor has the highest score compared to the sour, salty and bitter taste receptors. Bitter taste could be felt across the surface of the tongue, but the bitter taste receptors located most dominantly on base of the tongue. On this area, the average examination score proved that bitter taste in the bitter taste receptor had the highest score compared to the sweet taste receptor, salty and sour. These results showed that taste buds scattered across the surface of the tongue, as well as microvilli contained there in which serves as a taste receptor. ${ }^{2}$ It was also stated that the overall flavor perception of the entire surface of the tongue, but one flavor will be more sensitive in certain area. ${ }^{11}$

Non-smokers were more sensitive to sweet taste in sweet taste receptors and more sensitive to sweet taste in salty taste receptors than smokers. The salty and bitter receptor sensitivity was between smokers and non-smokers did not differ significantly. These results were consistent with other research which stated that non-smokers had higher sense of taste sensitivity to sweet taste of sucrose solution than the smokers group. ${ }^{12}$ In addition, the scattered location of taste buds across the surface of the tongue implied that the sweet taste could be perceived not only in the sweet taste receptor, but in salt taste receptor as well. ${ }^{11}$

The bitter taste sensitivity was greater in non-smokers than smokers' cigarettes. These result was in accor- dance to a study indicated that among smokers, sweet, sour, salty and bitter sensations were more difficult to taste due to damage in the sensory nerve endings and taste buds on the tongue due to the heat generated of cigarette smoke. ${ }^{10}$

The study found that smokers had decreased taste perception compared to non-smokers. This was due to the chemical content of nicotine and tar contained in cigarettes. The absence of filter in cigarette causing the harmful agents such as nicotine and tar could easily caused taste bud damage.

\section{CONCLUSION}

The results of this study support the concept that constant irritation from the burning tobacco causes oral mucosal tissue thickening. This facilitated nicotine deposition in the membrane covering the taste buds and blocking the taste receptors around the taste pore. Smoking habit has reduced the sensitivity of taste receptors. All taste receptors could taste sweet and bitter substances but on certain location the taste receptors are more sensitive compared to others.

\section{REFERENCES}

1. Marya RK. A text book of physiology for dental students (Taste and Smell). New Delhi: CBS Publishers \& Distributors; 2002.

2. Ganong WF. Buku ajar fisiologi kedokteran (Pengecapan). Alih Bahasa. Djauhari Widjajakusumah. Jakarta: EGC Penerbit Buku Kedokteran; 2002. Indonesian.

3. Dewi D. Pengaruh kebiasaan merokok terhadap mukosa mulut. Dentika Dental Journal 2005;10:1325. Indonesian.

4. KOMPAS. 10 Negara dengan jumlah perokok terbesar di dunia [Internet]. 2009 [cited 2012 Jan 5]. Available from: http://nasional.kompas.com/ $\mathrm{read} / 2010 / 10 / 02 / 19280569 /$ Perokok. Indonesia. Terbesar Ketiga.Dunia. Indonesian.

5. Centers for disease control and prevention. Pendidikan yang rendah tingkatkan kebiasaan merokok. [Internet]. 2010 [cited 2012 Mar 23]. Available from: http://www.stopmerokok.com/post/quit-bites/ pendidikan-yang-rendah-tingkatkan-kebiasaanmerokok/>. Indonesian.

6. Sitepoe M. Kekhususan rokok Indonesia. Jakarta: PT Gramedia Widiasarana Indonesia; 2000. Indonesian.

7. Simon-Morton B, Farhat T. Recent finding on peer group influences on adolescent substance use. J Prim Prev. 2010;31:191-298.

8. Khurana Indu. Textbook of human physiology for dental students (Sense of Taste). New Delhi: Reed Elsevier India Pvt. Ltd;2007. p.767-70. 
9. Just T, Pau HW, Steiner S, Hummel T. Assessment of oral trigeminal sensitivity in humans. Eur Arch Otorhinolaryngol. 2007;264:545-51.

10. Mulyawati Y. Pengaruh rokok terhadap kesehatan gigi dan mulut. Subdit Gizi klinis, Direktorat Gizi Masyarakat, Departemen Kesehatan RI. 2004. Indonesian. [cited 2012 Jan 5]. Available from http:// indonesiaindonesia.com/f/7726-pengaruh-rokokkesehatan-gigi-mulut/

11. Purves D, Augustine GJ, Fitzpatrick D, et al., edi- tors. Neuroscience. 2nd edition. Sunderland (MA): Sinauer Associates; 2001. Taste Perception in Humans. Available from: http://www.ncbi.nlm.nih.gov/ books/NBK10833/

12. Sukarno AD, Irmawati A, Yuliati. Perbedaan sensitivitas indera pengecap rasa manis pada perokok dan non perokok. Media Majalah Ilmu Faal Indonesia. 2008. [cited 2012 Jan 5]. Available from: http://journal.unair.ac.id/filerPDF/abstrak_318429_tpjua.pdf 